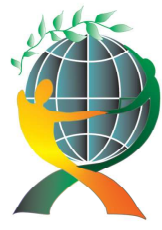

\author{
(online) $=$ ISSN $2285-3642$ \\ ISSN-L = $2285-3642$ \\ Journal of Economic Development, Environment and People \\ Volume 6, Issue 2, 2017
}

URL: http://jedep.spiruharet.ro

e-mail: office jedep@spiruharet.ro

\title{
Factors that Could Affect the Financial Sustainability of the Pension System in Romania
}

\author{
Luise Mladen ${ }^{1,2}$ and Mihaela Ghența ${ }^{1}$ \\ ${ }^{1}$ National Scientific Research Institute for Labour and Social Protection \\ ${ }^{2}$ SpiruHaret University
}

\begin{abstract}
In Romania, the Social State Security Budget spending exceeds the revenues, and this situation leads to a growing deficit of the public budget. This evolution is the result of many factors, more or less difficult to be managed, which we analyze in this article. The phenomenon of ageing has a significant role in increasing the pressure on the social protection systems, in general, and on the pension system, in particular. Also, the labour market related factors and the economic factors have an important impact on the sustainability of the pension system. The design of the pension system is equally important.
\end{abstract}

Keywords: pension systems, ageing, financial sustainability

JEL Codes: H55, J26

\section{Introduction}

The aim of this study is to analyse the factors that could threat the sustainability of the Romanian pension system. European projections on demographic evolution raise concerns regarding the ageing of population for the next 20-30 years. It is well known that such a phenomenon will have a significant impact and will increase the pressure on social protection systems in general, and on the pension system in particular.

Romania, similarly to other European countries, has implemented a number of legislative changes in pensions's field in order to adapt it to demographic and economic changes. Because Romania's demographic and economic development takes place in an international context, but also in order to understand the influences exercised in the national legal and economic sphere, a comparative approach, pointing the place occupied by Romania among the EU countries, is the most comprehensive.

When it comes to the sustainability of pension systems, it is important not only the financial stability, but also objectives like of poverty alleviation in old age by providing an adequate income after retirement[1].

The factors considered to have a significant influence on the sustainability of the pension system, are:

- Demographic factors;

- Labour market related factors;

- Economic factors;

- Factors related to the design of the pension system. 


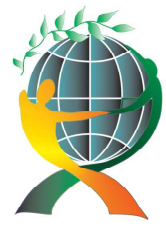

\author{
(online) $=$ ISSN $2285-3642$ \\ ISSN-L = $2285-3642$ \\ Journal of Economic Development, Environment and People \\ Volume 6, Issue2, 2017
}

URL: http://jedep.spiruharet.ro

e-mail: office jedep@spiruharet.ro

In Romania, the State Social Security Budget (BASS) spending exceeds the revenues, and this situation leads to a growing deficit of the public budget. It can easily be noticed that the problems in providing the necessary resources for the payment of pensions and other expenditures of the BASS appeared in 1995. During 1995-2005, the budget recorded deficits, more or less accentuated. It is only in 2006 that the situation recovered and, for two consecutive years, the BASS showed surpluses. As a result of the growth of the pension point from $32 \%$ to $45 \%$ of the average salary in 2008 , the BASS pressure started to increase, followed by substantial annual transfers from the state budget, necessary for the payment of pensions. In addition, since Pillar II became operational in 2008, some of the contributions to the public pension system were redirected to the mandatory private pension scheme. As the contribution to the second pillar increased (from 2\% in 2008 to $5.1 \%$ in 2016 and 2017) and the number of participants in this pension scheme rise, the public deficit grew from $0.44 \%$ of GDP in 2008 to a maximum of $2.55 \%$ of GDP in 2015 . In 2016 , the deficit slightly reduced to $1.95 \%$ of GDP.

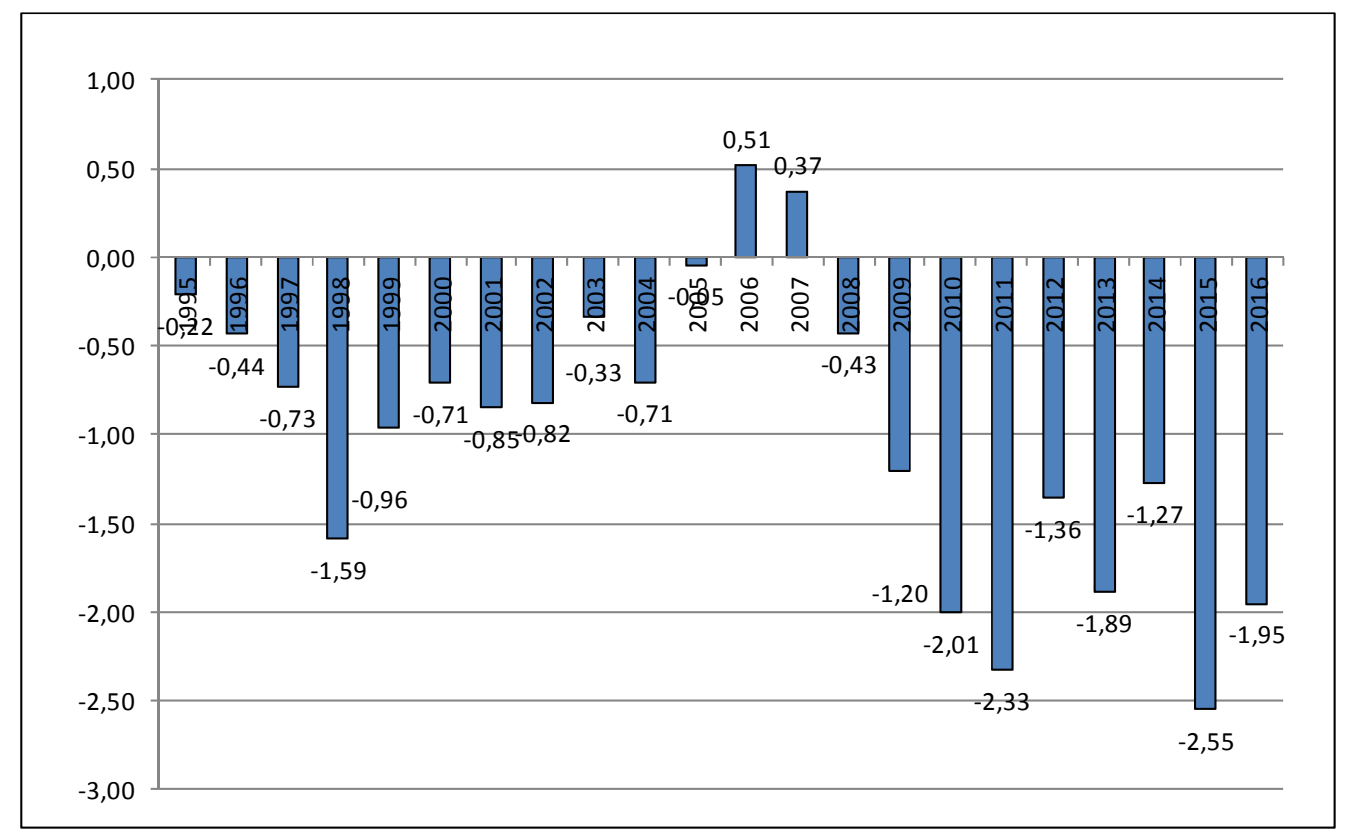

Fig. 1: BASS deficits as percentage of GDP, 1995-2016

Source: calculated by authors based on INS, on-line database (1995-2015)and Ministry of Public Finances(2016)

The following picture shows an important expansion of state subsidies necessary to balance the BASS. 

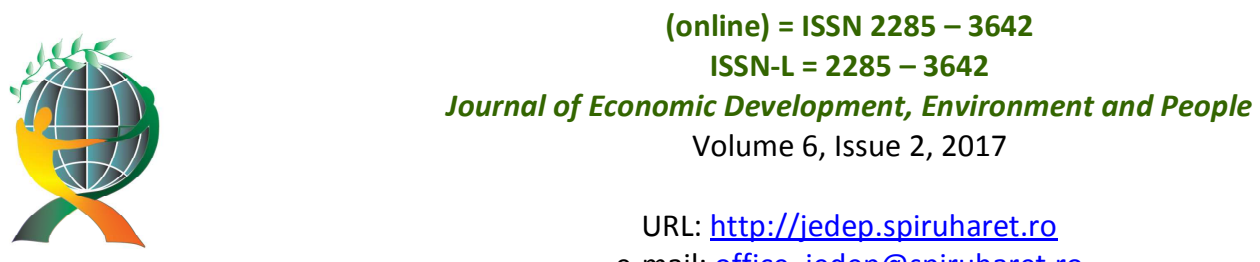

URL: http://jedep.spiruharet.ro e-mail: office jedep@spiruharet.ro

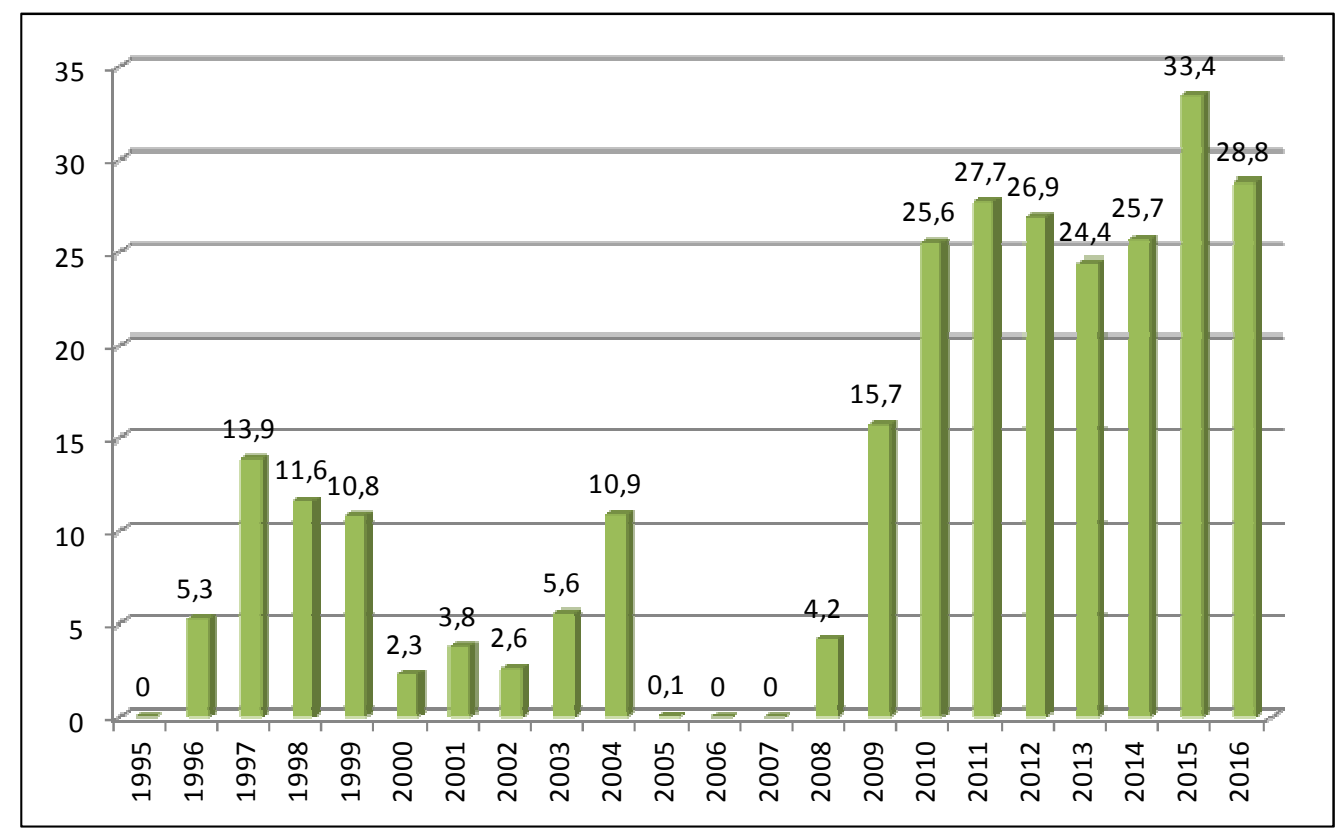

Fig. 2: State subsidies as percentage of BASS revenues (\%)

Source: calculated by authors based on INS, on-line database (1995-2015)and Ministry of Public Finances(2016)

The impact of the government's decisions towards the end of 2008 has reflected in the level of BASS expenditures as a share of GDP. These expenditures grew sharply from $5.5 \%$ in 2007 to $8.5 \%$ in 2011 . During 2012-2016, the public expenditures on pensions have oscillated but have not exceeded $8 \%$ of GDP. The correspondence coefficient between the increase in BASS expenditure and the GDP growth for the whole analysed period (1995-2016) is 1.28, underlying a faster increase in BASS expenditure relative to GDP growth.

At this stage we have analysed both the factors that have led to deficits of the state social insurance budget, as well as the factors that have a potential impact on the future sustainability of the Romanian pension system.

\section{Demographic factors}

At national level, the share of the overall population aged 65 years and over in total population, followed an upward trend during 2007-2016. The total increase was 2.7 p.p. (from $14.7 \%$ in 2007 to $17.4 \%$ in 2016), with a higher increase for women - 3.4 p.p. than the growth accounted for males - 2 p.p. Although the specific proportion of this population increases, it remains below the EU28 average of $19.2 \%$ (for year 2016). However, the growth rate is higher in Romania. 

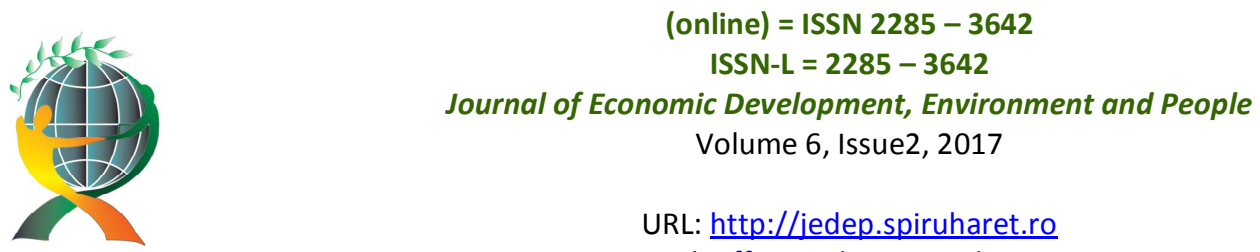

URL: http://jedep.spiruharet.ro

e-mail: office jedep@spiruharet.ro

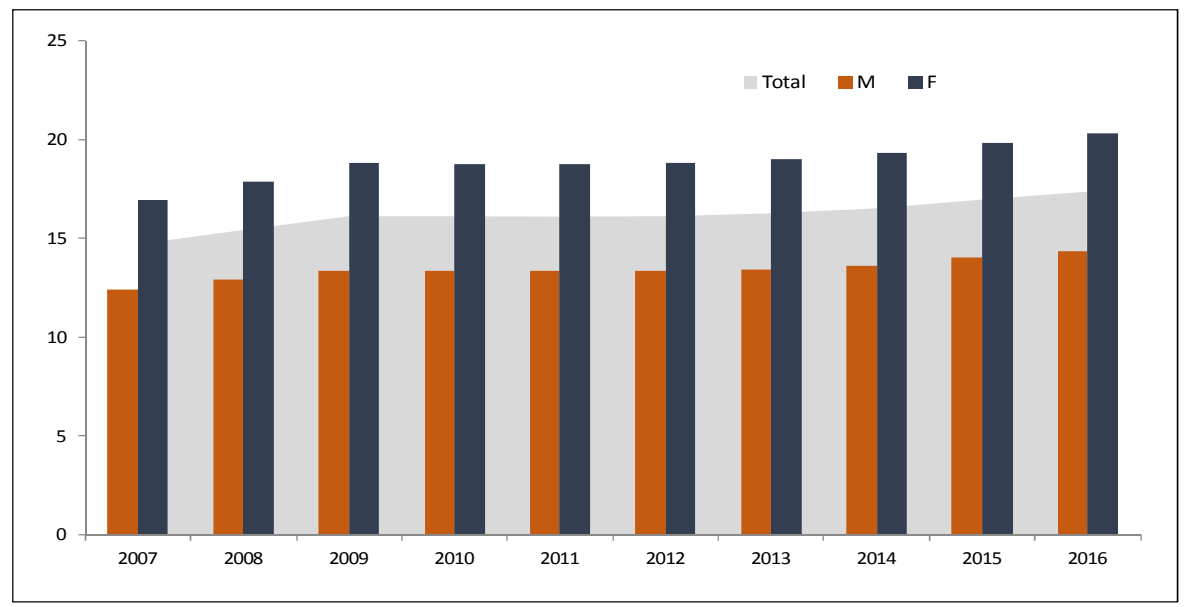

Fig.3: Share of the population aged 65 and over in the total population, in Romania (\%)

Source: Eurostat, online data code [demo_pjanbroad]

Projections regarding the evolution of the population aged 65 and above are pessimistic for all European countries. By 2050, the most significant growths are expected in countries such as Greece, Italy, and Lithuania. The share of Romanian population aged 65 and over will reach $29.8 \%$ of total population in 2050, above the EU 28 average of $28.5 \%$. Therefore, the elderly will represent almost one third of Romania's population in 2050.

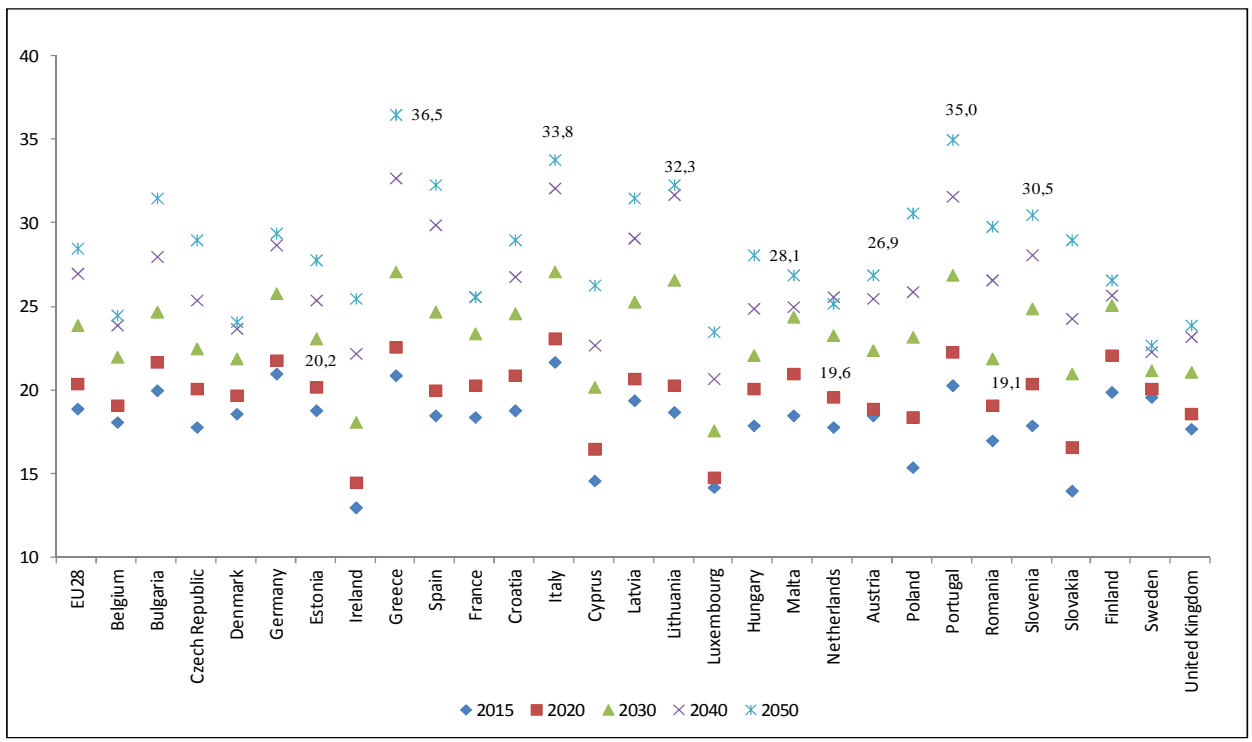

Fig.4: Evolution of the share of population aged 65 and over, 2015-2050 (\%)

Source: Eurostat, online data code [proj_15ndbims] 


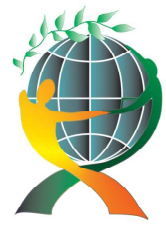

\author{
(online) $=$ ISSN $2285-3642$ \\ ISSN-L = $2285-3642$ \\ Journal of Economic Development, Environment and People \\ Volume 6, Issue 2, 2017
}

URL: http://jedep.spiruharet.ro

e-mail: office jedep@spiruharet.ro

These demographic changes are the consequence of two factors. The first factor is the increase in life expectancy, and the second is linked to the strong decline in birth rates.

Life expectancy at birth has been following an upward trend in recent years, with a maximum of 75.1 years reached in Romania, in 2013. Although, life expectancy at birth has steadily stood below the EU average during 2007-2015, at a difference ranging from 5.4 to 6.2 years. Compared to other former communist East European countries, Romania recorded one of the smallest increases in the life expectancy at birth during 2007-2015, of only 1.9 years. Significant rises in the life expectancy at birth occurred in the case of Baltic countries: Estonia (registered an increase of 4.8 years), Latvia (an increase in life expectancy of 4 years) and Lithuania (an increase of 3.9 years).

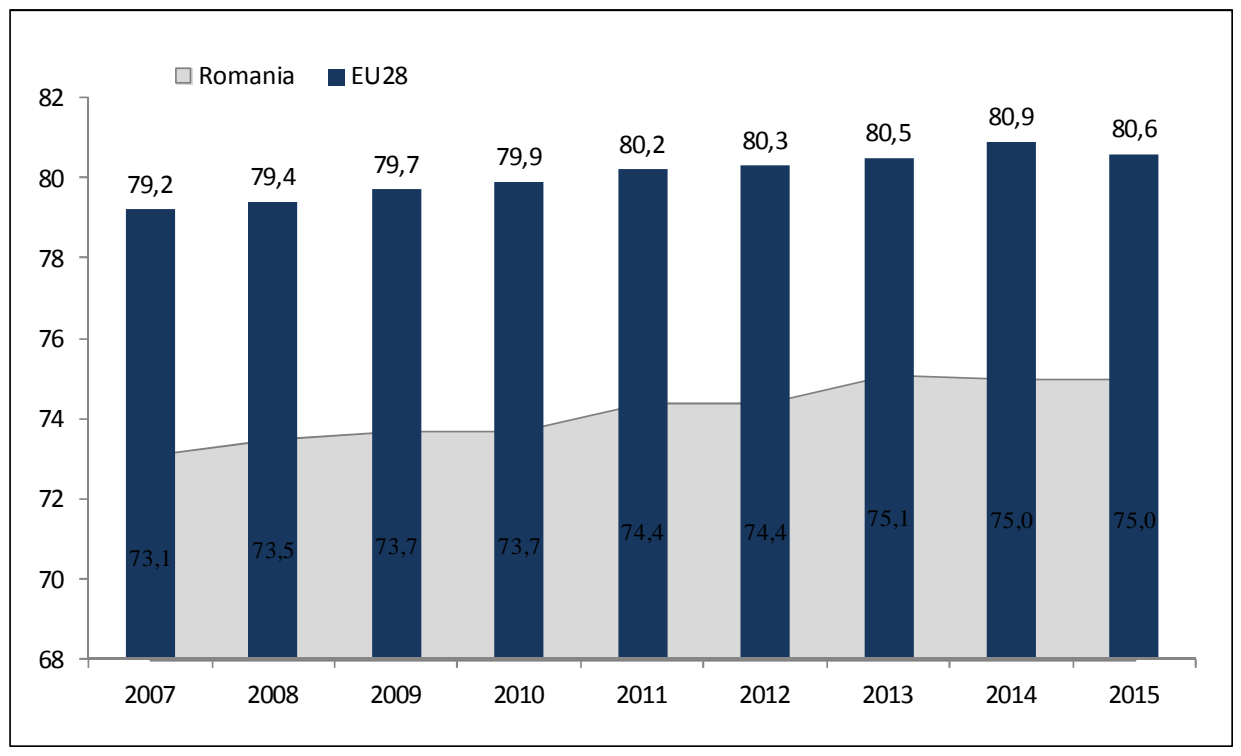

Fig.5: Life expectancy at birth (years)

Source: Eurostat, online data code [demo_mlexpec]

For the sustainability of the pension systems, life expectancy at 65 years old is an important indicator from the perspective of the standard retirement age. There are still considerable differences between women and men in terms of life expectancy at age 65. At national level, life expectancy at the age of 65 has risen during 2007-2015, in a greater extent for women, with approximately 3-3.5 years, compared to the estimated life expectancy for men aged 65. Between 2015 and 2050, projections of life expectancy at age 65 for Romania, indicate a growth of 5 years in the case of men and 4.9 years for women. In 2050, life expectancy at 65 years for men is projected to reach 19.5 years, and 22.8 years for women. In the case of Romania, increases in life expectancy at birth and life expectancy at the age of 65 did not necessarily correlate with a similar increase in healthy life expectancy. Our country is part of the group of countries that have experienced reductions of healthy life expectancy during 2007 and 2015, both in the case of women (by 2.1 years) and men (by 1.3 years). 


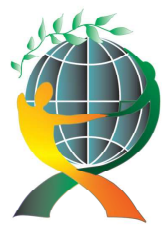

\author{
(online) = ISSN $2285-3642$ \\ ISSN-L = $2285-3642$ \\ Journal of Economic Development, Environment and People \\ Volume 6, Issue2, 2017
}

URL: http://jedep.spiruharet.ro

e-mail: office jedep@spiruharet.ro

\begin{tabular}{|c|c|c|c|c|c|c|c|c|c|c|}
\hline & & 2007 & 2008 & 2009 & 2010 & 2011 & 2012 & 2013 & 2014 & 2015 \\
\hline \multirow[t]{2}{*}{ Life expectancy at birth } & $M$ & 69,5 & 69,7 & 69,8 & 70,0 & 70,8 & 70,9 & 71,6 & 71,4 & 71,5 \\
\hline & $\mathrm{F}$ & 76,8 & 77,5 & 77,7 & 77,7 & 78,2 & 78,1 & 78,7 & 78,7 & 78,7 \\
\hline \multirow[t]{2}{*}{ Life expectancy at 65} & $M$ & 13,9 & 14,2 & 14,3 & 14,2 & 14,5 & 14,4 & 14,7 & 14,7 & 14,5 \\
\hline & $\mathrm{F}$ & 16,9 & 17,7 & 17,8 & 17,6 & 17,8 & 17,7 & 18,1 & 18,1 & 18,0 \\
\hline \multirow{2}{*}{$\begin{array}{l}\text { Healthy life years in } \\
\text { absolute value at } 65\end{array}$} & $M$ & 7,6 & 7,9 & 7,2 & 5,9 & 5,4 & 5,9 & 5,8 & 5,9 & 6,3 \\
\hline & $\mathrm{F}$ & 7,8 & 8,0 & 7,1 & 5,1 & 4,7 & 5,1 & 5,2 & 5,7 & 5,7 \\
\hline
\end{tabular}

Table 1: Evolution of the life expectancy (years)

Source: Eurostat, online data code [demo_mlexpec]; [hlth_hlye]

Birth rate has followed a downward trend in Romania, dropping from 9.5 live births to one thousand inhabitants in 2007 to only 9 live births per thousand inhabitants in 2015. These levels are well below the level recorded in 1990, of 13.6 live births per thousand inhabitants. The natural growth of the population as a result of the birth rate and the general mortality trend has been declining. In 1990 the rate of natural increase was positive, of 3 per 1000 inhabitants and by 1992 it has become negative and has remained so until today. In 2015, the last year of the series, the natural increase rate was -2.8 .

The old-age dependency ratio (the ratio of population aged 65 to over to the population aged 15-64) reached $25.9 \%$ in Romania in 2016, being slightly below the average EU 28 of $29.3 \%$. Compared to 2007, the increase accounted 4.4 p.p. in the case of Romania, compared to an increase of 4.1 p.p. of the EU average.

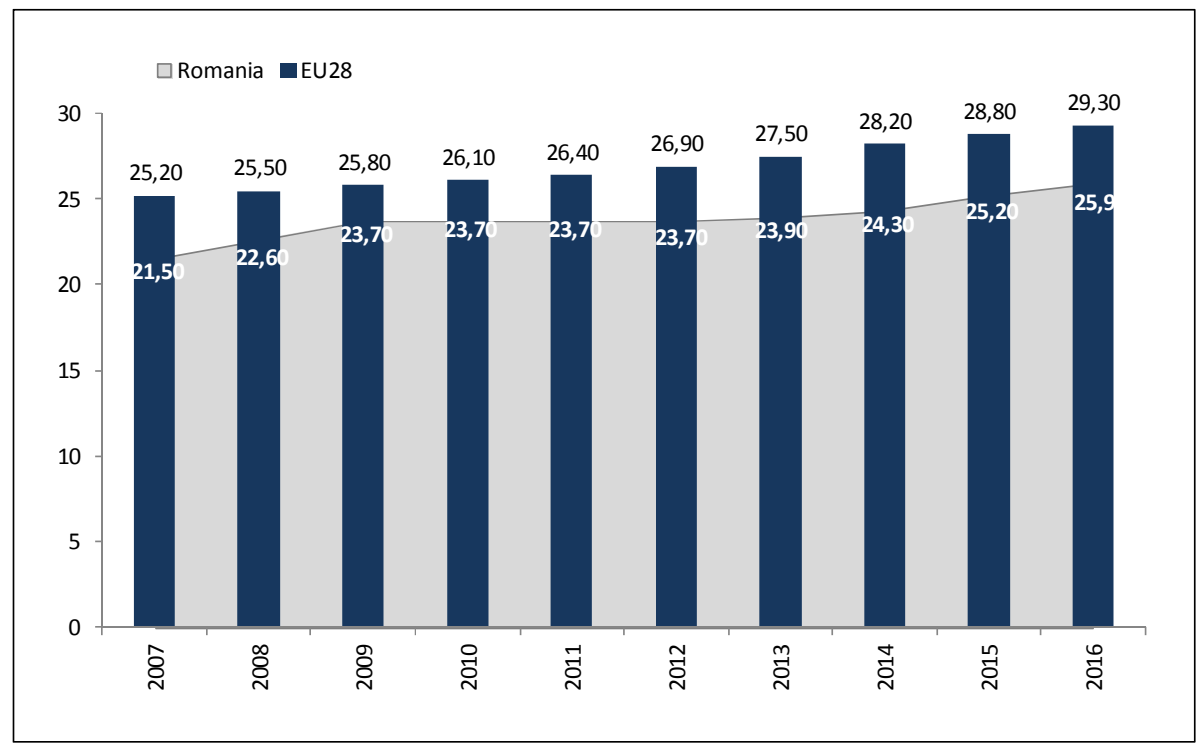

Fig.6: Old dependency ratio (population 65 and over to population 15 to64 years) (\%)

Source: Eurostat, online data code [demo_pjanind] 


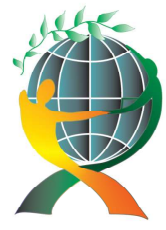

\author{
(online) $=$ ISSN $2285-3642$ \\ ISSN-L = $2285-3642$ \\ Journal of Economic Development, Environment and People \\ Volume 6, Issue 2, 2017
}

URL: http://jedep.spiruharet.ro

e-mail: office jedep@spiruharet.ro

The old-age dependency ratio is expected to sharply rise in all EU Member States but, compared to the EU 28 average, it will increase at a faster pace in the Central and Eastern European countries. For the next 15 to 30 years, the estimates of the indicators evolution are pessimistic. For the first 15 years, the growth of the old-age dependency ratio at European level will reach a growth of 10.3 p.p. compared with 2015, and will almost double in 30 years (an increase of 21.5 p.p.). In Romania, the situation is even more dramatic, the value of this indicator rises by 28.7 p.p. (from $25.2 \%$ in 2015 to $53.9 \%$ in 2050). In this case, the effect of the demographic ageing will be felt very strongly after 2030, when more numerous generations, born during 1967-1990, will begin to retire. In this context, the budgets of pension systems have to bear the pension payments for a larger number of pensioners, beneficiaries of the public pension system, with a smaller number of taxpayers, employees and social security contributors. Statistical data already shows that this redistributive system can no longer operate on a sustainable basis in the face of the demographic problems.

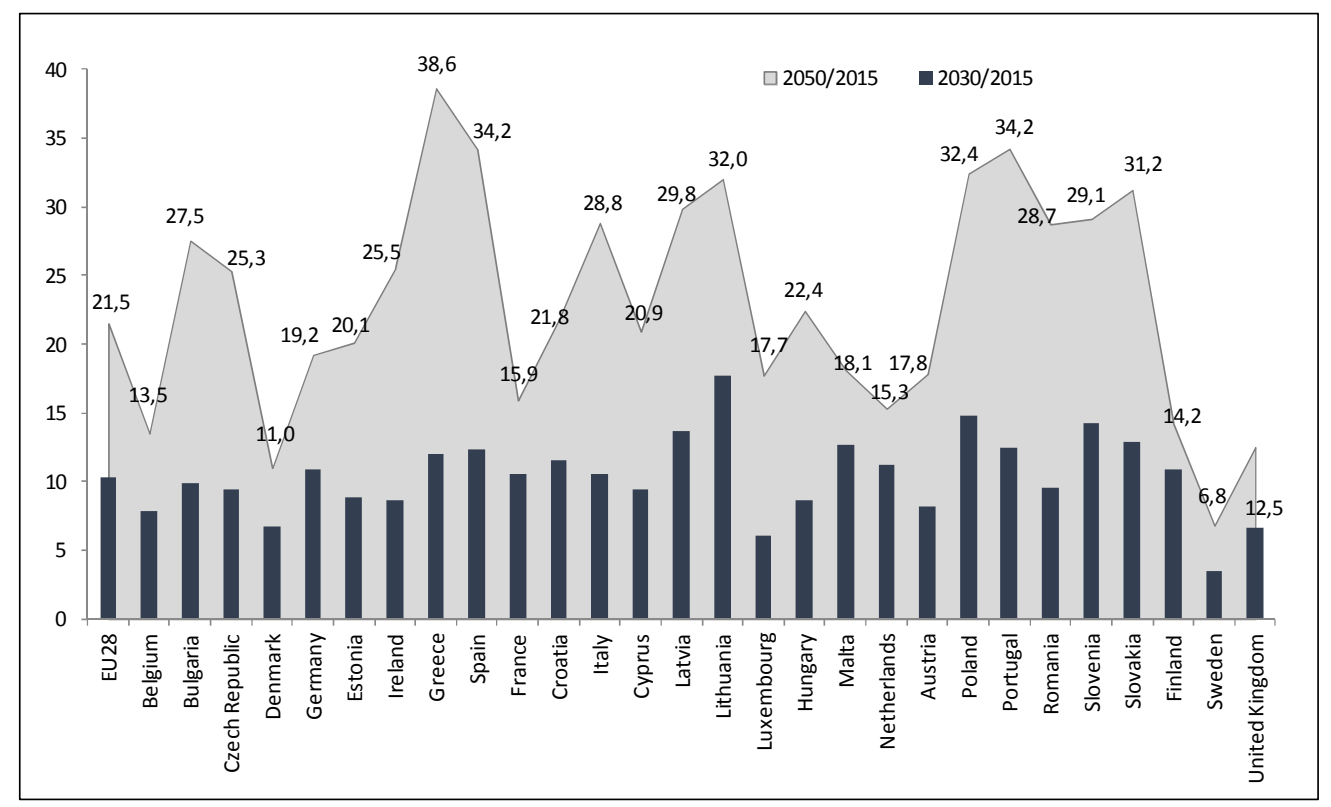

Fig.7: The dynamics of the elderly old dependency ratio (\%)

Source: Eurostat, online data code [demo_pjanind]

The demographic aging has also been accompanied by another trend, the early exit of older workers from the labour market, increasing the ratio of pensioners to contributors, with negative consequences on the sustainability of the system.

Demographic ageing may affect not only the public pension system but also the private pensions. Ageing societies may reduce the potential growth rate of the economy, which would translate in lower real investment returns with effects on the price of the financial assets. Any reduction in placements returns 


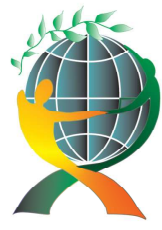

\author{
(online) $=$ ISSN $2285-3642$ \\ ISSN-L = $2285-3642$ \\ Journal of Economic Development, Environment and People \\ Volume 6, Issue2, 2017 \\ URL: $\underline{\text { http://jedep.spiruharet.ro }}$ \\ e-mail: office jedep@spiruharet.ro
}

made through pension funds may lead to an increase in contributions, a cut in pensions or risk-taking to a greater extent.

\title{
3. Labour market related factors
}

In recent years, the labour market has undergone many fundamental changes that make it necessary to reflect on their consequences on the social protection system in general and on the pension system in particular. Changes of the labour market with a major impact on pension systems are related to free movement of labour, increased flexibility of employment contracts, and the large share of self-employed workers. There are also a number of transformations produced by the phenomenon of globalization. Unemployment itself is a challenge for pension systems, with both individual and macroeconomic effects. High unemployment means fewer contributors to the pension system, having a negative impact on the financial sustainability of the system and also on the adequacy of future pensions as long as their level is correlated with the contributions paid during the active life.

In Romania, the activity rates are well below the EU28 average. In 2016, the total activity rate in our country was $65.6 \%$, while the EU28 average rate was $72.9 \%$. The activity rate of the male population is clearly higher than that of the female population in our country (74.8\% vs. 56.2\%) and at the EU28 level (78.5\% compared to 67.3\%). The employment rates for the working age population (15-64 years) are lower in Romania compared to the EU28 average rate in all of the years of the analyzed period. In 2016, the total employment rate in our country reached only $61.6 \%, 5$ p.p. lower than that of the EU28, but the increase registered compared to 2007 is 2.8 p.p., while at the EU28 average level is only 1.3 p.p. Major differences arise between employment rates by gender and by age groups. In 2016, in Romania the male employment rate was $69.7 \%$ compared to $53.3 \%$ which represents the female employment rate, resulting in a difference of 16.4 pp. Also at EU28 level, men are favoured, but the difference is lower, of 10.4 p.p., the male employment rate being $71.8 \%$ and the one of the females $61.4 \%$. Analyzing occupancy rates by age groups, there are small values for the 55-64 age group (55.3\% for EU28 and $42.8 \%$ for Romania) compared to the 25-54 age group (78.7\% for EU28 and 77.6\% for Romania) at the level of 2016.

A tendency with many negative consequences on the social and budgetary level is the lower share of employees in the employed population in Romania compared to the average of the European countries (in 2016, $75.7 \%$ compared to $85.0 \%$ ). Such a socio-professional structure is reflected in the decline of the income security, of the saving capacity, of the investment in education and training, and last but not least the reduction in the coverage of the pension system. This development has also resulted in a higher level of labour taxes.

Regarding the evolution of the employed population in the main sectors of activity, there is a general trend in decreasing the employment rate in agriculture and industry and an increase in services. In our country, however, still remains a considerable surplus of labour resources in agriculture, a sector with low added value. Increasing employment in the service sector significantly changes the nature of work, labour relations and organization of work. Flexible organization of work and working hours characterizes this development. Such a change in the occupational structure implies the emergence of less paid jobs, often part-time and temporary. 


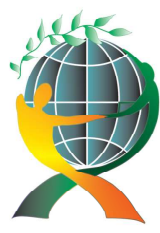

\author{
(online) $=$ ISSN $2285-3642$ \\ ISSN-L = $2285-3642$ \\ Journal of Economic Development, Environment and People \\ Volume 6, Issue 2, 2017 \\ URL: http://jedep.spiruharet.ro \\ e-mail: office jedep@spiruharet.ro
}

\title{
4. Economic factors
}

The state's economy directly influences the financial sustainability of the pension systems. The GDP is the total output available for consumption for all inhabitants of a country in a calendar year. The benefits paid to the elderly come from the current GDP and the larger the share of the GDP that the retirees have, the more limited will be the consumption opportunities for the other population categories. The risk to the financial sustainability of the pension system comes from the fluctuations and negative shocks in the evolution of the GDP, these having an immediate impact on available resources that can be distributed to the society, including to pensioners[2].

The recently overcome crisis has and will also have a major impact on public expenditure on pensions. In addition to the immediate effects produced by the reduction of the base for social security contributions due to economic contraction and rising unemployment, it should also be taken into account the future consequences of the increase in debt stock that will lead to an increase of the public service debt level.

The crisis has demonstrated the need to balance the PAYG system with the private pension systems, even though both types of pension systems are affected by the economic crises. These phenomena generally have a strong impact on financial markets. The decrease in interest rates and the value of financial assets affects the yields/returns and the solvency of funded pension schemes.

The shadow economy and the poor collection of contributions are another factor that can affect on long-term the sustainability of the pension system. In Romania there is a shadow economy in which about 1-2 million people work. Often, employers refuse to register the entire salary of employees, thus the declared base for calculating insurance contributions is greatly diminished compared to the real one. There are also situations when no contributions are paid at all, since the workers are not registered with the labour inspectorate. This leads to poorer resources for state social insurance budget.

The size of the shadow economy in Romania and other countries of the European Union is revealed by Schneider et all[3]. According to these authors, the estimation of the shadow economy size is made in relation to the GDP, as the share held in the GDP by the economic activities related to the black economy.

\begin{tabular}{|lllllllll|}
\hline RO & 2007 & 2008 & 2009 & 2010 & 2011 & 2012 & 2013 & 2014 \\
UE & 30,2 & 29,4 & 29,4 & 29,8 & 29,6 & 29,1 & 28,4 & 28,1 \\
& 20,3 & 19,6 & 20,1 & 19,9 & 19,6 & 19,3 & 18,8 & 18,6 \\
\hline
\end{tabular}

Table 2: The size of the shadow economy in \% of GDP over the period 2007-2014

Source: Schneider, F., Raczkowski, K., Mroz, B., 2015, pp. 45.

In the year 2014, Romania ranks second in the European Union, in terms of the size of the black economy as a percentage of the GDP, just after Bulgaria (31\%). 


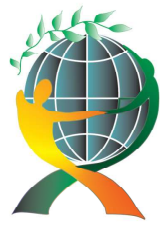

\author{
(online) $=$ ISSN $2285-3642$ \\ ISSN-L = $2285-3642$ \\ Journal of Economic Development, Environment and People \\ Volume 6, Issue2, 2017 \\ URL: $\underline{\text { http://jedep.spiruharet.ro }}$ \\ e-mail: office jedep@spiruharet.ro
}

\title{
5. Factors related to the design of the pension system
}

The introduction of mandatory private pensions and the redirection of a part of the social security contributions to Pillar II is a challenge for the State Social Security Budget. Since 2008, some of the employee contributions have supplied individual pension funds, the initial contribution rate being of $2 \%$ and rising to $6 \%$ by 2018 . In this situation, the resources that the social state insurance budget will have available will be greatly diminished.

The size of the statutory retirement ages for both men and women, the size of the minimum contribution period for obtaining the old age pension, the pension calculation method and the correlation between the pension level and the salary earnings over the entire active period, the eligibility requirements for early retirement pensions and for invalidity, the pension indexation formula are other factors that have an impact on the sustainability of the pension system.

\section{Conclusions}

The sustainability of the pension systems is important, since the pension revenues are the main source of income for the elderly. Like other European countries, Romania faces the need to secure long-term stability of the public pension system in order to be able to absorb the impact of the demographic aging phenomenon. From this perspective, the sustainability of the pension system implies an achievement of a balance between the number of contributors and beneficiaries. In addition, with the fall in employment rates and the rise in public pension costs, the national pension system may not be able to provide the social protection needed for future generations of retirees. In order to avoid such a situation, it is recommended to implement policies that have the effect of increasing labour productivity, but also increasing employment among the active population.

\section{Acknowledgements}

This paper is part of a study directed by the Dr.Luise Mladen and is financed from the funds of the National Research, Development and Innovation Plan (PNCDI - Planul National de Cercetare, Dezvoltare si Inovare, Program NUCLEU 2016-18) under the contract number PN 16440402.

\section{References}

[1] A. G.Grech. Assessing the sustainability of pension reforms in Europe, 2010. Available online at http://sticerd.Ise.ac.uk/dps/case/cp/CASEpaper140.pdf

[2] B. Mattil. Pension Systems: sustainability and distributional effects in Germany and the United Kingdom, Springer Science \& Business, 2006.

[3] F.Schneider, K. Raczkowski, B.Mroz. Shadow Economy and tax evasion in the EU. Journal of Money Laundering Control, Vol. 18(1), 2015, 34-51. 